Zbl. Vet. Med. C. Anat. Histol. Embryol. 7, 226-244 (1978)

(C) 1978 Verlag Paul Parey, Berlin und Hamburg

ISSN 0340-2096/ASTM-Coden: AHEMA5

\author{
${ }^{1}$ Division of Biological Sciences, The University of Michigan \\ Ann Arbor, Michigan 48109, U.S.A. \\ 2 Department of Zoology, Universitaire Instelling Antwerpen, \\ 2610 Wilrijk, Belgium
}

\title{
Analysis of Mammalian Masticatory Mechanisms: Progress and Problems
}

\author{
By \\ Carl Gans ${ }^{1}$, Fritz de Vree ${ }^{2}$, and Gerard C. Gorniak ${ }^{1}$
}

With one table

(Received for publication February 15, 1978)

\section{Introduction}

Table of contents: Introduction, Mastication - Cautions for analysis. First level analysis, Muscle arrangements, Meaning of the electromyogram, Recording of movements, Strain and strain gauges, Energetic costs of reduction, Control of masticatory orbits, References.

The mammals are unique among the vertebrates in the tremendous diversity of their masticatory apparatus. Most taxonomic schemes (cf. Simpson, 1945) rely heavily on the arrangement and structure of mammalian teeth and even the classification of fossils is based primarily upon dentitional characteristics (ROMER, 1966; OLsON, 1971; BUTLER, 1972; CROMPTON/JENKINS, 1973). This diversification of the adult dentition perhaps reflects in some way the relatively slight growth during the period in which most mammals use this set of teeth for feeding; a recent study suggests that this may be a reflection of the promotion of initial growth in the young by combined placentation and lactation (POND, 1977) and of limiting the absolute size of adults by determinate growth. In any case, mammals are unique in the extent to which their radiation reflects feeding habits, a situation shown by past morphological and theoretical analyses of the mammalian masticatory apparatus (SMITH/SAvAGE, 1959; SCHUMACHER, 1961; Turnbull, 1970).

Many studies relating teeth to mastication approach the subject from the aspects of wear patterns and the formation of tooth facets (cf. ANTHONY, 1935; ANTHONY/FRIANT, 1936; Mills, 1967; Gingerich, 1972, 1973, 1974, 1976; CROMPTON, 1971, 1972; KAY, 1975; KAY/Hitemae, 1974 a; Osborn/Crompton, 1973; Rensaerger, 1973). This approach is obviously important in the analysis and reconstruction of masticatory patterns in fossils. The last decade has seen an explosive increase both in the number of and the data provided by experimental studies of the masticatory apparatus of several orders of mammals. We now have detailed measurements of the movements, coupled with the muscular activity and sometimes the forces generated by mammals from several major groupings (Table 1). Many of these studies have now been carried out on conscious, unanesthetized, freely feeding animals, so that the observed behavior is presumably close to normal. Similar analytical studies are becoming available on various reptiles, such as Spbenodon (Rosenberg/Gans, 1977), agamid lizards (Throckmorton, 1976) and snakes (Cundali/Gans, 1977). Analyses of diverse other lizards are in process.

U. S. Copyright Clearance Center Code Statement: 0340—2096/78/0703—0226\$02.50/0 
Table 1

Experimental studies on mammalian mastication

\begin{tabular}{|c|c|c|c|c|c|c|}
\hline Order & Species & Authors & Cine & $\begin{array}{l}\text { Techn } \\
\text { Cine- } \\
\text { radio }\end{array}$ & EMG & Motion \\
\hline Marsupiala & Didelphis virginiana & $\begin{array}{l}\text { CROMPton / Hilemae, 1970 } \\
\text { HIIEMAE / Crompton, 1971; } \\
\text { CROMPTON et al, 1975, } 1977\end{array}$ & $\begin{array}{l}- \\
- \\
\end{array}$ & $\begin{array}{l}+ \\
+ \\
+\end{array}$ & $\begin{array}{l}- \\
+ \\
+\end{array}$ & $\begin{array}{l}- \\
- \\
\end{array}$ \\
\hline Insectivora & $\begin{array}{l}\text { Tenrec ecaudatus } \\
\text { Tupaia glis }\end{array}$ & $\begin{array}{l}\text { CROMPTON et al, } 1977 \\
\text { HIIEMAE / KAY, } 1973\end{array}$ & - & $\begin{array}{l}+ \\
+\end{array}$ & - & - \\
\hline Chiroptera & $\begin{array}{l}\text { Myotis lucifugus } \\
\text { Pteropus giganteus }\end{array}$ & $\begin{array}{l}\text { KALLEN / GANS, } 1972 \\
\text { STORCH, } 1968 \\
\end{array}$ & + & - & + & - \\
\hline Primates & $\begin{array}{l}\text { Galago crassicaudatus } \\
\text { Saimiri sciureus } \\
\text { Ateles belzelbuth } \\
\text { Macaca mulatta } \\
\text { Homo sapiens }\end{array}$ & $\begin{array}{l}\text { KaY / HIIEMAE, 1974 b; } \\
\text { HYLANDER, 1977 } \\
\text { HIIEMAE / KAY, 1973 } \\
\text { HIIEMAE / KAY, 1973 } \\
\text { MCNAMARA, 1972, 1974; } \\
\text { LUSCHEI / GOOOWIN, 1974 } \\
\text { MOYERS, 1950; } \\
\text { CARLSÓb, 1952; } \\
\text { GREENFIELO / WYKE, 1956; } \\
\text { JARABAK, 1957; } \\
\text { AHLREN, 1966; } \\
\text { MøLLER, 1966; } \\
\text { VITTI / BASMAJIAN, 1977 }\end{array}$ & $\begin{array}{l}- \\
- \\
- \\
- \\
- \\
- \\
- \\
- \\
- \\
- \\
+ \\
\text { TV }\end{array}$ & $\begin{array}{l}+ \\
- \\
+ \\
+ \\
- \\
- \\
- \\
- \\
- \\
- \\
- \\
- \\
-\end{array}$ & $\begin{array}{l}- \\
- \\
- \\
- \\
+ \\
+ \\
+ \\
+ \\
+ \\
+ \\
+ \\
+ \\
+\end{array}$ & $\begin{array}{l}- \\
S \\
- \\
- \\
- \\
M \\
- \\
- \\
- \\
- \\
- \\
- \\
-\end{array}$ \\
\hline Lagomorpha & Oryctolagus cuniculus & ARDRAN et al, 1958 & - & + & - & - \\
\hline Rodentia & $\begin{array}{l}\text { Mesocricetus auratus } \\
\text { Ratlus norvegicus } \\
\text { Cavia porcellus } \\
\text { Capromys pilorides } \\
\text { Plagiodontia aedium } \\
\text { Myocastor coypus }\end{array}$ & $\begin{array}{l}\text { GORNIAK, 1977 b } \\
\text { HIIEMAE / ARORAN, 1968; } \\
\text { WEIJS, 1975; WEIJS / DANTUMA, } 1975 \\
\text { OE VREE, } 1977 \\
\text { WOODS, } 1976 \\
\text { WOODS, } 1976 \\
\text { BECHT, 1953; } \\
\text { WOODS, 1976 } \\
\end{array}$ & $\begin{array}{l}+ \\
- \\
+ \\
+ \\
+ \\
+ \\
+ \\
+\end{array}$ & $\begin{array}{l}- \\
+ \\
+ \\
- \\
+ \\
+ \\
+ \\
+\end{array}$ & $\begin{array}{l}+ \\
- \\
+ \\
- \\
- \\
- \\
-\end{array}$ & $\begin{array}{l}- \\
- \\
- \\
- \\
-\end{array}$ \\
\hline Carnivora & Felis domestica & 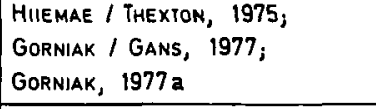 & $\begin{array}{l}- \\
+ \\
+\end{array}$ & $\begin{array}{l}+ \\
- \\
-\end{array}$ & $\begin{array}{l}- \\
+ \\
+\end{array}$ & - \\
\hline Perissodactyla & Equus caballus & ВEсHT, 1953 & + & - & - & - \\
\hline Artiodactyla & $\begin{array}{l}\text { Sus scrofa } \\
\text { Cervus elaphus } \\
\text { Capra hircus } \\
\text { Bos indicus } \\
\text { Bos taurus } \\
\text { Bison bonasus }\end{array}$ & 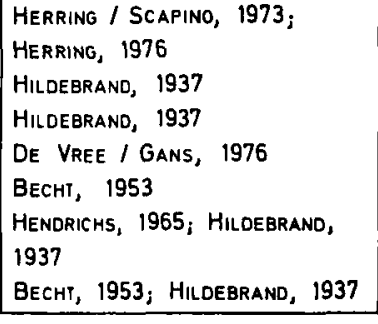 & $\begin{array}{l}+ \\
+ \\
+ \\
+ \\
+ \\
+ \\
+ \\
+\end{array}$ & $\begin{array}{l}+ \\
- \\
- \\
- \\
- \\
- \\
- \\
-\end{array}$ & $\begin{array}{l}+ \\
+ \\
- \\
- \\
+ \\
- \\
-\end{array}$ & $\begin{array}{l}- \\
- \\
- \\
- \\
A \\
- \\
- \\
-\end{array}$ \\
\hline
\end{tabular}

$\mathrm{A}=$ accelerometer $\mathrm{M}=$ motion transducer $\mathrm{S}=$ strain gauge on mandible; $\mathrm{TV}=$ television

Simultaneously the sophistication of the experimental techniques applicable to the analyses of functional problems has increased markedly, as have the tools generally available for measurement of the physical characteristics of masticatory systems. In addition we have progressed in our appreciation of muscle in terms of its ultrastructure, histochemistry, physiology, and control (Close, 1972; Burke/Edgerton, 1975; Wetzel/StuarT, 1976; Goslow, 1978). Data pertinent to an understanding of the mammalian masticatory system are being provided from the areas of anatomy, physiology, zoology, anthropology, paleontology, and 
dentistry. Consequently, the time is appropriate to compile and review what we have learned thus far and to ask which questions and techniques might now be the most appropriate ones.

\section{Mastication - Cautions for analysis}

The more recent studies of mastication have involved what may be excessive generalization because of our desire to apply laboratory analytic techniques to conscious animals. One such generalization has been due to the subdivision of the continuous movement into more or less standardized masticatory orbits through which the mandible moves in repeated quasiperiodic orbital cycles. The shape and number of such orbits has long been the subject of study with the initial approach based on observation and cinematography. Orbits have more recently been characterized further based upon cinefluoroscopic records, or from the output of strain gauges. Furthermore, electromyographical data have been correlated with movement information in a number of studies.

This reliance upon standard orbits permitted a convenient shorthand that was useful during the first analytical stage and provided an initial basis for comparisons among animals. It now seems important to call attention to three apsects of mastication. The first is that mastication prepares food for disgestion. Thus, the relation of the changing condition of the food particles to the movement of the mandible should be the primary object of study. The second is that the orbit is only an indirect and incomplete indicator of one aspect of the food-reduction process. The third is that the jaws, soft tissues and dentition may reflect the influence of natural selection for the performance of other equally critical biological roles.

The first of these three aspects forces us to consider the food and its preparation as primary. The repetitive masticatory cycles have been emphasized; also critical are preparatory cutting and reduction cycles, and the terminal clearing (cleaning) orbits prior to swallowing. Thick-shelled beetles may have to be crushed, while thin-shelled larvae may only need to be shredded. Leaves and grasses need to be sheared and multiply abraded to break the cell walls and expose the contents, while seeds and fruits may only need to be crushed or abraded to increase the surface area available for chemical digestion. While the influence of food type differs among species, movement analyses and simultaneous electromyograms show clearly that food has a significant effect on the number of masticatory orbits required to prepare each bolus for swallowing, on the shape of successive orbits and with this on the firing rate and magnitude of activity in the muscles propelling the jaws (DE Vree / Gans, 1973, 1976; Hiremae/Thexton, 1975; Thexton/ Hilemae, 1975; Gorniak, 1977 b; Gorniak/Gans, 1977). This aspect suggests not only that food type be taken into account, but also that some effort be made to consider how each species deals with its natural foods; indeed the texture of preparations designed for domesticated or zoo stock may deserve further attention.

The second aspect is that the teeth and jaws clearly are not the only components of the masticatory system involved in the reduction of food. Even after food has been cut off and initially positioned between the tooth rows, each orbit is followed by a new repositioning movement replacing the food between the dentitional surfaces. Consequently one must deal with the mechanism by which the bolus is shifted, in terms of movements of hyoid and tongue and those of the cheeks. Only a few studies have thus far offered some details of the activity patterns in the tongue and throat muscles (Herring/Scapino, 1973; Weijs/Dantuma, 1975; Crompton et al., 1977), 
though others are apparently under way. While various hyoid muscles have been shown to fire in synchrony with the several phases of mastication, their actual mechanical actions are still poorly understood. It is likely that they assist opening movements of the jaws and they certainly participate in repositioning the soft tissues of the buccal floor.

The action of the nuchal musculature may also be important in shifting some food objects between the teeth. In certain species this action apparently induces jerking movements of the head and transmits forces to the bolus either shifting it inertially or shifting the head about it when the mouth is opened (GANs, 1969; Gans/Kallen, 1972; Gorniak, 1977 a). By such movements the animal may perform some of the work of food reduction with the nuchal musculature, and needs not to increase the mass of its more distally located cranial muscles. It remains to be seen whether restraint of animals during feeding has an effect on the masticatory pattern. Furthermore, the significance of inertial movements may vary with the size and consistency of the bolus.

The third aspect indicates that the buccal apparatus, soft tissues and teeth are obviously involved not only in food reduction, but also in the initial procurement of food, whether this be by stabbing or eviscerating the prey, by cutting plant material as for instance in grazing or browsing, or by peeling nutritious bark from twigs and branches (ARDRAN/KEMP, 1960; Hitemae/Ardran, 1968; Herring/Scapino, 1973; Weijs/Dantuma, 1975; GoRNIAK, 1977 b). The teeth may be very important for cutting segments of food; however, there are multiple independent solutions to each such problem. Leaves can be gathered by action of the lips and palate (manatee and rhino), by a protrusible tongue (giraffe and okapi), and by a prehensile trunk (tapir and elephant). Clearly, the behavior of the animal has to be considered in functional analyses. Teeth and buccal structures have further biological roles in such diverse aspects as grooming, display, tunnel formation, burrowing, defense (cf. Thexton/Hiremae, 1977), aggressive interactions, and the transport of young and of nest material. Not all specializations of the masticatory apparatus can thus be explained in terms of food reduction, nor should one assume that tooth architecture "perfectly" reflects to any one role. Comparative analysis is required to distinguish the multiple potential selective influences.

To summarize: It may be useful to consider masticatory function in terms of the demands the animal has for a particular reduction scheme for those food types upon which it is likely to rely in the wild. In characterizing specializations of the buccal apparatus we also have to take into account that other biological roles may have affected the development of the buccal structures we observe.

\section{First level analysis}

Thus far analysis of masticatory systems has sampled widely, with primary investigations emphasizing the major feeding types (SMITH/SAVAGE, 1959; Turnbull, 1970). The results have supported the basic justification of these schemes, but have also uncovered an only partly understood complexity.

The masticatory orbits of mammals show no clear or logical point from which to start a description. Movement is generally continuous; however, instead of thinking of pure vertical, pure transversal or pure propalineal movement, we must recognize that orbits are generally three-dimensional and displacements may thus occur simultaneously in more than one plane. In all mammals thus far studied, the masticatory orbit can be divided into 
three phases or strokes: a first phase (closing, preparatory) in which the mouth closes, a second phase (working, power) in which the food is reduced and a third phase (opening, recovery) in which the jaws open. Further subdividions have been suggested for various mammals, generally by dividing off the end of the first and the second phases (CROMPTON et al., 1975, 1977). This may be appropriate for particular species, but seems in most other forms to be dependent on food type (DE VReE / Gans, 1973, 1976; Hilemae, 1976). Beyond this general outline (preparatory, working and recovery strokes), there is clearly no simple "mammalian" masticatory pattern and the individual movements may well be as diverse as the dentitional types.

Three surprising observations have been made at different points of investigation. First is the generality of alternating mastication, second the continuity of movement and the departures from simple planar orbits and third the overlapping nature of the motor patterns.

1. Most mammals seem to masticate on one side or the other in various alternating sequences. While some rodents represent exceptions to this, and only shift their teeth in a propalineal pattern, other rodents also exhibit left/ right alternation (DE VREE, 1977; GoRNIAK, $1977 \mathrm{~b}$ ). Movements of the tongue and lips seem to shift the food toward or beyond the active, working, or ipsilateral side whenever the jaws are widely separated. The generally mediad motion of the mandible on the working side then drives all or part of the food across the tooth rows cutting or shearing the food while the cusps move past each other. (In species that use essentially propalineal grinding movements, the power stroke occurs in a rostrad direction.) The opposing tooth rows appear to remain out of direct contact for most of the orbits of a sequence; mainly the food will be in contact with both sets of cusps on the working side, and a portion of the food will be transferred across the "contact" surface on that side during the closed portion of each orbit. Unless the stroke is followed by a switch of the working side, the food will be transferred back toward the original position when the jaw opens again.

2. Rather than swinging in simply definable propalineal or transverse planes, masticatory orbits of almost all mammals appear to proceed in an asymmetrical fashion. The jaws generally move in three-dimensional space, so that downward rotation at the condyles is coupled with unilateral or bilateral condylar translation. All phases of the orbit are affected by the nature and size of the food particles; thus goats and cats show different orbital configuration when the food type is changed, as well as during successive reduction cycles (DE VREE / GANS, 1976; GoRNIAK/GANS, 1977).

The complexity is best demonstrated by reviewing a general cycle:

i. During the first (closing, preparatory) phase the mandible moves rapidly toward the upper jaw. This phase involves a lateral displacement, though variable in time of onset and extent, of the lower jaw towards the ipsilateral (working or active) side. The vertical movement then slows apparently as soon as both upper and lower teeth contact the food. The moment of contact depends upon the type and initial size of the food, as well as upon the position of the particular orbit in the reduction sequence. The horizontal movement reverses at or just before contact.

ii. While the vertical movements of the lower jaw are minimal during the second phase, in which it reaches the maximum closed position (for a particular orbit), the jaw continues to move, swinging medially and rostrally depending on the species (while the food is crushed, cut or ground). The extent of the transverse and rostrad components during this phase clearly depend not only upon the shape of the molars and their occlusion pattern, but also upon 
the position of the molar rows relative to the sagittal and horizontal planes (cf. the inclinations seen in rat, hamster, and guinea pig), the structure of the mandibular joints and meniscal ligaments and cartilages (SCAPINO, 1965; GasPard, 1971; BeEcher, 1977; Noyes/Salt, 1977) and the nature of the food.

iii. During the third (opening, recovery) phase some of the teeth lose contact with the food as the mandible drops to the wide open position. In some mammals the opening jaw initially continues to travel toward the contralateral (passive, balancing) side and to be protruded simultaneously. The movement of the jaw then reverses and the jaw is retracted as it accelerates toward the wide open position. While the mouth opens, the tongue seems to collect the food from the linguad aspect of the working side and to shift it back across the tooth row toward the cheek. The duration and extent of mandibular depression are thus influenced by the need to move the bolus.

There is some difficulty with the definition and possible subdivison of the second phase. Its start obviously depends on the instant of contact of food and teeth, and thus on the size of the object(s) being reduced. Some authors (HIIEMAE/ARDRAN, 1968) furthermore suggest that a "power stroke" ends with the teeth in occlusion, i. e. at their most dorsal position, and there is mention of slow closing and slow opening phases. However, in man, in some primates and in ruminants the dentition continues to work on the food beyond the "power" portion of phase two. Certainly the lower molars clear the food from the upper ones during the shift from occlusion. Thus the subdivisons of the second phase are not yet comparable among all mammals studied and the most closed position of the mandible need not necessarily correspond to the end of the application of "power" (see electromyographic results below). In many species the shape of the molar cusps may involve further shearing of food during continuation of medial movement of the mandible, beyond the line of maximal occlusion. Perhaps the entire phase two had best be referred to as a "reduction" phase.

3. The electromyographical patterns confirm the asymmetry of movement and show that both time course and magnitude of the firing amplitude may differ between working and balancing sides. Rather than being neatly subdivided into openers and closers, acting during well-defined portions of masticatory orbits, the muscles appear to be electrically active for protracted, widely overlapping periods that need not simply correlate with direction of movement, but reflect the interval that the mandible seems to exert forces on the food. EMG also documents the intrinsic asymmetry of masticatory movement as the food is shifted from side to side. However, asymmetric movements need not involve asymmetric EMG activity in all muscles; in the hamster, the superficial masseter and medial pterygoid fire asymmetrically while the left and right deep masseters do not differ significantly in activity.

The difficulty with the preceding description is that it is qualitative and for most organisms lacks a comparative basis. There is some further question as to whether we have as yet sampled enough species to confirm the generality of these observations. As the lateral and propalineal displacements become nearly equivalent, the orbits have to be defined in three-dimensional terms; simple descriptive schemes become more difficult. Polar bar graphs attempting to provide a comparative basis (Kallen/GANS, 1972; DE VREE / GANs, 1976) are far enough from the ordinary analytic repertoire to pose some conceptual difficulties. Almost none of the studies offered thus far provide quantitative information on the number of orbits that were indeed analyzed and on the techniques by which the congruence of their geometrical shapes was 
compared. We very much need descriptors that will facilitate simple, biologically meaningful comparisons among the movements used for different food types, by different individuals, and for different species.

\section{Muscle arrangements}

The majority of the fibers of skeletal muscles involved in voluntary muscular activity are "fast" or "slow" acting twitch fiber, differing further in their oxidative properties (TAYLOR et al., 1973; SUzuki, 1977; GosLow, 1978). Tonic fibers only occur in some highly specialized mammalian muscles (Hess, 1970) and do not appear to contribute to the electromyogram. Each muscle unit is composed of fibers of a single type, sharing the same contractile properties, and all innervated by a single motoneuron.

The evidence is becoming overwhelming that even adjacent portions of muscles may differ in morphology and functional properties. Analysis is easiest in parallel-fibered strap muscles that originate and insert via welldefined tendons. The vectors produced in contraction will then act in limited areas and from limited directions. Pinnate muscles are of ten more complex and show radiating tendons with complex subdivisions; the muscle fibers occupying these subdivisions may be of different lengths and placed at varying angles (GANs/Bock, 1965). We may expect and have some confirming evidence that these independently innervated subdivisons need not be active simultaneously (Gydikov/Kosarov, 1973; BotTERMan et al., 1978). The action may be sequential during a masticatory movement, and different motor units may act at different times for different foods or in different roles (HERring, 1977).

Another important consideration in structural analysis is the profile of fiber properties characterizing each of the miscellaneous motor units. Work by BURKE (1978) documents that the gastrocnemius muscle contains four kinds of twitch fibers, each with distinct contractile properties; the slow fibers of the soleus do not fit this scheme. The suggests that we are likely to discover an extensive function-associated fiber differentiation in jaw muscles as well. It will probably be necessary to engage in a time-consuming process of preliminary mapping of the kinds of fiber types found in the masticatory muscles, determining the properties of ead, checking their distribution within each muscle, and ultimately determining their recruitment sequence. This is certainly critical for the understanding of force application during mastication, particularly as recruitment pattern indeed proceeds differently and sequentially for the several sets of fiber types (Grimby/HanNerz, 1968; Olson et al., 1968; Gydikov/Kosarov, 1973; HATZE/BuYs, 1977; EDGERTON, 1978). It should also be mentioned that such considerations potentially pose some problems for the construction of various kinds of models intended to permit comparisons of the muscular mechanisms of extinct vertebrates.

\section{Meaning of the electromyogram}

Electromyography (EMG) is a technique for recording the changes in electrical potential at some site within or near a muscle. Depending upon the size and configuration of the electrodes one determines electrical events in a relatively narrow area. Stimulation via one of a pair of adjacent electrodes (and recording from the second) suggests that electrical transmission is limited to fractions of millimetres and that connective tissues, fasciae and aponeuroses generally provide good dielectric barriers. 
Consequently small, twisted intramuscular electrodes should give a good indication of local conditions (BIGLAND/LipPold, 1954). Indeed we know that single-fiber electromyograms provide reasonably repetitive information about the activity of particular motor units (BURKE et al., 1973; EKSTEDT/STALLERG, 1973; STÅLBERG/EKSTEDT, 1973). Furthermore, an electrode located in a particular region of a muscle will produce signals that have good (but not necessarily linear) correlation with the effort the muscle in performing in carrying out a particular movement (i. e. with effort of ventilation, GAUNT/ GANS, 1969; strength of biting, GoRNIAK/GANs, 1977). However, the literature of electromyography is replete with statements suggesting that the recordings of extracellular electrodes are not quantitative but only qualitative descriptors of muscular activity. What explains this supposed difference?

The extracellular EMG formerly taken with needle electrodes (and sometimes from the surface) is now generally taken with a set of bare wire electrode tips one or more millimetres in length; this is large relative to the diameter but not compared to the length of the muscle fiber. The electrode may only sample a small portion of the total responses of any particular motor unit. On the other hand, it is likely to pick up signals from all those motor units that have one or more fibers in a particular area. Activation of each of these presumably produces a transient change in the potential between the tips of the electrode; the magnitude of the change reflects the impedance of the electrode and the sensitivity of the recording equipment. Hence the electrode detects electrical events of different apparent voltages. Their number, magnitude and duration will reflect the distance of the active muscle fibers from the various portions of the electrode and as well as the number of fibers producing simultaneous signals.

Under these circumstances the architecture of the muscle (GANs/Bock, 1965 ) and its contractile properties (BURKE/EDGERTON, 1975) become critical. The former will determine the arrangement of motor units and the latter the number and magnitude of voltage changes produced by each. The probability of obtaining repeatable results in sampling multiple sites of a single muscle is obviously completely different in a parallel-fibered strap muscle, with widely overlapping motor units, and a pinnate muscle, the motor units of which may have highly localized fields (BUCHTHAL et al., 1959; BURKE, 1978). The component parts of pinnate muscles are often defined by tendinous associations and may furthermore differ regionally in their cytochemical and contractile properties. As most muscles are more or less complexly pinnate, random placement of the electrodes within them will obviously affect the reproducibility of the recordings.

The classical length tension curve apparently describes the force produced by a muscle which is stimulated at a particular length without shortening or stretching further during the contractile event. However, muscles affecting animal movements may induce forces while changing their length; they may shorten or be stretched at varying rates. Both the tension generated under these circumstances and the energy required for contraction depart markedly from the classical relation. Consequently, it is impossible to translate the electrical event in a motor unit directly into a tensile state or to read from it the amount of energy expended by the organism when it performs a particular biological role. Here again we note that the electromyogram cannot be used as a simple indicator of the "work" the animal is doing at a particular instance.

In summary the miscellaneous statements regarding the inappropriateness of electromyograms for certain procedures do not speak to the information 
that the EMG can provide, but document only that the EMG will not provide absolute answers. How can one improve the utility of an EMG and what can one learn from it? Optimum placement of electrodes would first of all requires some preliminary information regarding the fiber arrangement within a muscle and perhaps the location of the motor end plates on the fibers. Electrodes (of standardized shape and impedance) would always be placed in comparable sites in a muscle; when the muscle is subdivided into fascicles it would seem appropriate to place the electrodes into well defined subregions. Electrodes thus placed should give good indication of the onset and cessation of motor activity and of the relative magnitude of activity in a particular movement pattern. This protocol might be less than adequate in systems of limited constraint, such as the freely positioned muscles in the trunk of an elephant; here one cannot simply estimate relative shortening of particular elements from external positions of the entire trunk. However, the positions and length of fibers (and thus their position on the length-tension curve) should be reasonably equivalent, for instance, for similar excursions in each orbit of a masticatory sequence.

We have little information whether recuritment of motor units within one subset of a motoneuron pool proceeds in an absolutely predetermined or in a statistical pattern; the latter would seem to be more plausible. If motor units are recruited statistically, we would expect slight differences in the EMG observed by a single electrode at a single site in a muscle firing under absolutely equivalent conditions. This suggests that EMGs must be evaluated, not as absolutely repeatable individual events, but as sequences of events that cluster about a mean value. It also suggests that the analysis of EMGs should be automated and expressed as mean number and magnitude derived from the electrical occurrences for series of similar mechanical events (such as, the initial orbit in the mastication of a food object of particulat sizc, shape and consistency).

\section{Recording of movements}

Automated electromyography in which multiple electrical events are summed and compared to multiple specific movements and force applications also requires readily obtained, reliable and computer scannable records of mechanical events. Techniques are available for digitization of cinematographic and closed-circuit television images including those of cineradiographs. The output of sonic pens and point plotters can be rapidly transformed into displacement records and these into acceleration graphs that are most easily correlated with the EMGs of the muscles which presumably produce the forces that induce the acceleration.

However, such pictorial approaches are relatively indirect. The analysis is tedious and often extremely expensive in terms of the initial equipment needed, the number of investigator-hours that must be expended per minute of movement by the animal, and the film required for recording the protracted sequences of mastication (which of ten proceed at one to seven cycles per second). There may be a tendency to film too slowly and information may be lost unless the film speed is routinely monitored. Mastication may occur on one or the other side and the alternation between sides need not be regular. Size and shape of orbits will be affected by food type and bolus size. Large numbers of orbits need to be scanned to separate out the diverse components. Hence, there is a significant advantage to direct recording of movements and elimination of the intermediate image analysis. 
Such position transducing systems have been developed for the analysis of masticatory movements using LEDs (light-emitting diodes) or sound sources positioned on the jaws (Luschei/Goodwin, 1974; Herring, 1976). The sound signal may, for instance, be received by a triaxial arrangement of antennas. Unfortunately such systems. require that the animals be severely restrained and that the skull be clamped into position, so that the movements recorded will be those of the jaws alone, uncomplicated by shifts of the entire head. Another direct reading technique involves the application of mercury strain gauges and their use as movement indicators. Positions on the surface of the animal are sampled until one locates a pair of sites between which a good record of regular movements is obtained. Small accelerometers may be similarly attached to the mandibular symphysis of larger animals (GANS / DE VREE, 1974); however, the commercially available accelerometers may be relatively large which imposes the risk that their mass may affect the shape and frequency of the masticatory cycle.

While direct recording methods have great advantages, the output of transducers, including that from the strain gauges discussed below, cannot be used initially as absolute descriptors of movement; rather their output must be related first to mandibular movements as determined by pictorial approaches. Appropriate placement of accelerometers and movement indicators should permit definition of the critical events in each orbit, for instance, shifts of directions, peak accelerations and similar aspects (DE VREE / GANS, 1973). These may thus become acceptable indicators of coincident mandibular position and acceleration. They have the further advantages that they may be recorded on the same medium (magnetic tape or chart) as the electromyograms and that their characteristics may be scanned automatically coincident with the electromyogram.

\section{Strain and strain gauges}

Muscular action imposes forces on skeletal elements and the skull and mandible transmit these to the teeth and indirectly to the food. The forces establish stress levels within the bones and it seems interesting to consider these.

The direct determination of the forces exerted by muscles working in situ has recently become possible by the attachment of buckle transducers to the distal tendons, a simple and elegant technique utilizing small strain gauges (BURKE, 1978). The initial applications have been to the limb muscles of cats. However the technique may require some modification before it may be applied to jaw muscles with their wide tendons and complex fleshy insertions.

Bone strain, or the effect of the stress on bone, has long been a topic of interest in morphology. The developmental responses of bone to stresses have been argued for well over a hundred years and there are multiple techniques for visualizing the responses of the anisotropic material (such as the Spalteholz method, the Split line technique, and photoelastic modelling; Benninghoff, 1925; Ahrens, 1936; Seipel, 1948; Evans, 1953; TAppen, 1953, 1964; Kummer, 1966; EnIEF, 1966; Wright/Hayes, 1976). Recently we have seen the application of wafer strain gauges to the surfaces of bones, and with this the measurement of deformation within the immediately underlying bony tissue (KaKudo/Amano, 1970; Hylander, 1977; WeIJS / DE JONGH, 1977; BUCKLAND-WRIGHT, 1978). Applications of such strain gauges to mandibles show an increase of the strain with an application of muscular force. Indeed even the shell of turtles (GAUNT/GaNs, 1969) and the calvarium 
of young monkeys (BEHRENTs et al., 1978) show deformations with movements within the physiological range of the animal.

What is less clear is the absolute stress distribution within the bone, particularly when the shape is complex, the density uneven, and the central cavity variably filled. Theory suggests that while the stress concentrations will be localized, some increase in stress levels will also occur in the remaining zones of the bone. For instance the casque of the hornbill will participate in absorbing the stresses imposed when the animal bites into fruit; however, the reduction of the overall stress level thus obtained is presumably not a significant portion of the biological role of the structure. Tests have been run on multiple strain gauges attached to fresh skulls which were then loaded with mastication "equivalent" levels (ENDO, 1966, 1970; FisCHer et al., 1976). While such procedures require numerous complex assumptions they may provide order of magnitude estimates of stress levels. They should certainly provide a guide to the interpretation of the readings of strain gauges inserted in living animals as the latter have generally to be fixed to specific locations where no or few other tissues attach to the bone.

When coupled with recordings of mandibular deflection, strain gauges could also permit tests of the various hypotheses regarding the biological role of the symphysial joint (DU Brul / Sicher, 1954; SCAPINo, 1965; BeECHER, 1977). Action of the joint may reflect compensation for slight misalignment of the tooth rows and differences in crown height, which might affect the maximal area available for food reduction. Movements of the symphysis may also reflect the capacity of the animal to compensate for sudden shifts in the consistency of the food being reduced.

While mandibular strain gauges are unlikely in the immediate future and by themselves to yield data on absolute strain levels, they should facilitate clarification of events during the reduction phase of mastication. They may also help us to determine whether the mammalian of arrangement masticatory muscles indeed serves to reduce loadings on the temporomandibular joint (CROMPTON, 1966). When used together with buckle transducers they might also furnish cues about the role of possible elastic effects in the masticatory system.

\section{Energetic cost of reduction}

We know very little about the energy that an animal actually expends in reducing food. It has been suggested that those food types requiring harder or more prolonged masticatory sequences might require more energy, but these are hypotheses not measurements. The time involved in gathering food may be critical to some species and this consideration has been proposed as the basis for one advantage of rumination. Various kinds of elastic storage and later recorvery of energy have recently been shown to represent very significant components in various locomotor systems; while there are speculations that this may occur in mastication, there has, as yet, been no analysis.

The kinetic energy imparted to the closing jaws is obviously available for food reduction. It has been suggested that some of this energy will be conserved in the transitions among the three masticatory phases (DE VREE / GaNs, 1976). Some of the work done in compressing a bolus or stretching soft tissues may be recovered. A more closed position of the mandibular condyle relative to the tooth row is generally interpreted as being advantageous in the induction of shear forces within the food object; perhaps we should reexamine the suggestion, proposed for elephants (STÖCKER, 1957), that elevat- 
ed suspension allows the mandible to swing with the natural frequency of a pendulum, thus requiring less energy for continued movement. Such suggestions deserve test by direct measurement.

The diversity of mammalian dentitions suggests that the capacity to reduce various, but specific kinds of foods appears to have been critical to mammals; it appears plausible to suggest that some of the masticatory structures and patterns may reflect selection for a reduction of the energetic cost of food reduction as well.

\section{Control of masticatory orbits}

It is generally assumed that the basic masticatory cycle is under central control and that this established the basic sequence of muscular activity through successive orbits (SHERRINGTON, 1917; Bremer, 1923; Magoun et al., 1933; Rioch, 1934; Kawamura, 1967; Chase/McGinty, 1970; Dellow/Lund, 1971; Lund/Sessle, 1974; Thexton, 1976). It is also clear that external influences, such as the resistance of the food and the size of the bolus, will influence the shape of the masticatory orbit and the velocity of the jaw (DE VReE/Gans, 1973; Luschei/Goodwin, 1974; DE VReE/Gans, 1976; GorNiak, 1977 b; GoRniak/Gans, 1977). Three sets of receptors have been posited as having a critical role in the refining of masticatory motions. These are the mechanoreceptors in the joint capsule (KAWAmURA et al., 1967; KiINEBERg et al., 1970; KLINEBERG, 1971), the receptors of the dental ligaments (Jerge, 1964; Kidokoro et al., 1968; Hannam/Matthews, 1969; Hannam et al., 1970; Anderson et al., 1970; Daunton, 1977), and the muscle spindles and tendon organs of the masticatory musculature (SHERRINGton, 1917; Bremer, 1923; KaWAMURA et al., 1960; TAylor/Davey, 1968; Cody et al., 1972; Cody/TAYLOR, 1973; GoodwIN/LusCheI, 1974).

Most studies on the control of mastication have been performed on anesthetized or decerebrate cats and monkeys. These studies indicate that the interaction of the joint, dental and muscle receptors and of the central nervous system is very complex and that the results may vary in the same or different species.

Two examples illustrate these points. First, after the cell bodies of the muscle spindle afferents in the mesencephalic nucleus of $\mathrm{V}$ are destroyed, jaw movements recorded from unanesthetized rhesus monkeys (Macaca mulatta) show no significant changes, suggesting that the role of muscle spindles in controlling jaw movements may have been overemphasized (Goodwin/LusCHEI, 1974). Similar results are reported for bite-force response in rats (DAunTon, 1977). On the other hand, during active jaw movements in cats afferent activity has been recorded from muscle spindles to the cells of the mesencephalic nucleus with the activity related to masticatory movements (TAYlOR/DaveY, 1968; Cody/TAYLOR, 1973). Furthermore, cyclic motion of the jaws of cats and rabbits can be triggered by stimulating various areas of the cortex (SHERrington, 1917; MAgoun et al., 1933; Rioch, 1934; Kawamura, 1967; Chase/McGinty, 1970; Sumi, 1977), of the brain stem in decerebrate cats (Bremer, 1923; Magoun et al., 1933; Rioch, 1934; DenavitSaUbié/Corvisier, 1972), and of points along the dentition (Sherrington, 1917; BREMER, 1932; Jerge, 1964; Kidokoro et al., 1968; HanNam/ MATTHEWs, 1969). The role of these various receptors in refining masticatory motion and muscle activities with different food types and in protecting the teeth and the temporomandibular joint against possible overload is certainly unclear. Also unclear is the role of the tongue as a potential source of afferent input about the position and size of the bolus. 
Do these results apply only to the control process in anesthetized cats and monkeys? Is the control mechanism generally similar among mammals, even though these differ in dentitional pattern, skull and muscle architecture, muscle activity, jaw movements and feeding habits, or are there differences in control relating to species specific feeding behavior? We still lack answers. However, recent advances in technology now permit simultaneous recording of the afferent output from small populations of cell bodies as well as of jaw movements and the muscular activity in unrestrained, unanesthetized mammals. Comparative studies on diverse species would also be of interest.

\section{Conclusions}

This brief review has summarized the fundamental aspects of mastication in diverse mammals, as known today. It emphasizes the fate of the food object and notes the potential that biological roles, other than mastication, may have a significant effect on the structure of the mammalian face. The cheeks and tongue show cyclic movements for food positioning and the nuchal muscles may jerk the head for intertial placement of food while the jaws are apart. The data thus far available suggest that the orbital patterns seen are quite variable and depart from the stereotyped versions sometimes reported. Most mammals studied seem to chew on one side or the other during any given cycle; simultaneous bilateral chewing is rare. Orbits are generally complexly three-dimensional and combine propalineal and transverse movements with opening and closing. Muscular activity may occur throughout any portion of the masticatory orbit; while the greatest number of muscles is active during the start of the second phase, it is difficult to define phases by sharp transitions of electromyographic activity. The asymmetry of mandibular movements is clearly induced by asymmetric electromyograms. The distinct fascicles of the pinnate masticatory muscles apparently differ in fiber architecture and physiology, and function at different times (and with differing mechanical advantage). This suggests that such muscles should be sampled in more detail during future investigations.

The diversity observed among species, and the marked effects seen in response to food consistency and size complicate the search for and perhaps preclude generalizations at this moment. We need better methods for orbital comparison (simply scannable but accurate direct readings of movements), that may help to define biologically significant aspects among series of masticatory orbits differing in shape and duration. Further we require methods for correlating forces and excursions during multiple cycles with coinciden standardized electromyograms. Such approaches should facilitate tests of the statistical reliability of the descriptions. With this it should be possible to proceed to more subtle comparisons, for instance of the differences among members of a single genus. Clearly standardization of records and improved procedure for comparison are among the primary problems still retarding analyses and generalizations.

\section{Summary}

Direct measurement of bone movements and muscle activation in mammalian mastication is now possible. Early results indicate that the patterns are quite variable and depart from the stereotyped versions sometimes reported. Most mammals masticate unilaterally; only a few chew simultaneously on both sides. Orbital movements are complex and three-dimensional. While most muscles are active during the reduction phase, it is difficult to define phases by sharp transitions of activity. The fascicles of pinnate 
muscles differ in fiber architecture and physiology; they tend to function at different times and with distinct mechanical advantages.

Interspecific diversity and marked responses to food consistency and size, still preclude generalizations. Improved methods for comparisons among orbits, for correlation of forces and excursions, and automated correlations of movements, forces and electromyograms are beginning to be available and need to be more generally applied to analysis.

\section{Acknowledgements}

We thank B. D. Clark, H. J. de Jongh, J. A. Faulkner, G. E. Goslow, S. Herring, F. C. Kallen, L. C. Maxwell, P. Myers and T. C. Scanlon for comment on the manuscript. Supported by NSF DEB 77-02605 and NIH 5ROQ AM 18727-02 as well as a Fellowship (NIH 5F32 AM 05368-02) to G. C. Gorniak.

\section{Zusammenfassung}

Analyse der Kaumechanismen bei Säugern: Fortschritte und Probleme

Knochenbewegung und Muskelaktivität während des Kauvorganges bei Säugern sind heute direkt meßbar. Jüngste Ergebnisse zeigen, daß die Bewegungsmuster ziemlich stark variieren und nicht so stereotyp sind, wie zuweilen beschrieben wird. Die meisten Säuger kauen einseitig, nur einige beidseitig gleichzeitig. Die Kreisbewegungen sind komplex und dreidimensional. $\mathrm{Da}$ die meisten Muskeln während der Reduktionsphase aktiv sind, können Phasen auf Grund deutlicher Aktivitätsveränderungen kaum bestimmt werden. Die Faszikel der gefiederten Muskeln unterscheiden sich architektonisch und physiologisch; sie neigen dazu, ungleichzeitig und mit eigenen mechanischen Wirkungseffekten zu arbeiten.

Zwischenartliche Abweichungen und deutliche Unterschiede hinsichtlich der Konsistenz und Größe des Bissens schließen noch Verallgemeinerungen aus. Verbesserte Methoden für Vergleiche der Mahlbewegungen, zur Korrelierung von Kräften und Ausschlägen sowie für automatisierte Korrelationen von Bewegungen, Kräften und Elektromyogrammen werden zunehmend verfügbar und sollten verstärkt angewendet werden.

\section{Résumé}

\section{Analyse des mecanismes masticatoires des mammifères: Nouveaux aspects et problemes}

Il est maintenant possible d'effectuer des mesures directes des mouvements des os et de l'activité des muscles pendant la mastication chez les Mammifères. Les premiers résultats montrent que les modalités sont très variables et diffèrent des versions stéréotypées quelquefois exposées. Beaucoup de Mammifères mastiquent unilatéralement; quelques-uns seulement mastiquent simultanément des deux côtés. Les mouvements orbitaux sont complexes et s'effectuent dans les trois dimensions. Alors que beaucoup des muscles sont actifs pendant la phase de réduction il est difficile de définir les diverses phases par des changements nets d'activité. Les faisceaux des muscles pennés diffèrent par l'architecture et le fonctionnement de leurs fibres. Celles-ci ont tendance à fonctionner à des moments différents et avec des conséquences mécaniques diverses. La diversité interspécifique et les réponses nettes à la dimension et à la consistance des aliments ne permettent pas encore de généralisation. On commence à disposer de méthodes améliorées pour pouvoir comparer les mouvements orbitaux, la corrélation des forces exercées et des déplacements et la corrélation automatique des mouvements, les forces développées et les électromyogrammes; elles devraient être plus généralement appliquées à l'analyse. 


\section{Resumen}

\section{Análisis de los mecanismos de la masticación en los mamíferos: Progresos y Problemas}

Los movimientos de los huesos y la actividad muscular durante el proceso de la masticación en los mamíferos pueden medirse directamente. Los resultados más recientes demuestran una gran variabilidad de los tipos de movimientos, que no son tan estereotipados como a veces se describen. $\mathrm{La}$ mayoría de los mamíferos mastican unilateralmente y sólo algunos lo hacen simultaneamente en ambos lados. Los movimientos circulares son muy complejos y tridimensionales. Como la mayor parte de los músculos es activa durante la fase de la reducción, no se pueden determinar las fases tomando en cuenta cambios marcados de actividad. Los fascículos de los músculos se diferencian arquitectónica y fisiológicamente, tendiendo a trabajar a ritmo diferente y con efectos mecánicos particulares.

Discrepancias entre las especies y diferencias con respecto a la consistencia y el tamaño del bocado no permiten generalizaciones. Una metodología mejorada para la comparación de los movimientos masticatorios, para la correlación de movimientos y fuerzas y sus automatismos con los electromiogramas, está desarrollándose y debería aplicarse en mayor grado.

\section{References}

Ahlgren, J., 1966: Mechanism of mastication. Acta Odont. scand., 24 (Suppl. 44), 1-109.

Ahrens, H. J., 1936: Die Entwidklung der Spaltlinienarchitektur des knödhernen menschlichen Schädels. Morph. Jb., 77, 357-371.

Anderson, D. J., A. G. Hannam, and B. Matthews, 1970: Sensory mechanisms in mammalian teeth and their supporting structures. Physiol. Rev., S0, 171-195.

Anthony, R., 1935: Théorie de la dentition jugale mammalienne. In R. AnTHONY: Exposés d'Anatomie Comparée 1, 1-69. Hermann \& Cie., Paris.

Anthony, R., and M. FriAnt, 1936: Théorie de la dentition jugale mammalienne. In R. ANThonY: Exposes d'Anatomie Comparée. 2, 1-81. Hermann \& Cie., Paris.

Ardran, G. M., and F. H. Kemp, 1960: Biting and mastication. Dent. Practice, 77, 23-34.

Ardran, G. M., F. H. KemP, and W. L. D. RIDE, 1958: A radiographic analysis of mastication and swallowing in the domestic rabbit: Oryctolagus cuniculus (L.). Proc. zool. Soc. (London), 130, 257-274.

ВеCHT, G., 1953: Comparative biologic-anatomical researches on mastication in some mammals. Proc. kon. Ned. Akad. Wet. (C), 56, 508-527.

BEECHER, R. M., 1977: Function and fusion at the mandibular symphysis. Amer. J. Phys. Antrop., 47, 325-336.

Behrents, R. G., D. S. Carlson, and T. Abdelnour, 1978: In vivo analysis of bone strain about the sagittal suture in Macaca mulatta during masticatory movements. J. Dent. Res., (in press).

BenNinghoff, A., 1925: Spaltlinien am Knochen, eine Methode zur Ermittlung der Architektur platter Knochen. Verhandl. Anat. Ges., 34, 189-206.

Bigland, B., and O. C. J. Lippold, 1954: The relation between force, velocity, and integrated electrical activity in human muscle. J. Physiol., 123, 214-224.

Botterman, B. R., M. D. Binder, and D. G. StuART, 1978: Functional anatomy of the association between motor units and muscle receptors. Amer. Zool., 18 (2), in press.

Bremer, F., 1923: Physiologie nerveuse de la mastication chez le chat et le lapin. Reflexes de mastication. Résponses masticatrices corticales et centre corticale du goût. Arch. Intern. Physiol., 21, 308-352.

Buchthal, F., F. Erminio, and P. Rosenfalck, 1959: Motor unit territory in different human muscles. Acta. Physiol. Scand., 45, 72-87.

BUCKLAND-WRIGHT, J. C., 1978: Bone structure and the patterns of force transmission in the cat skull (Felis catus). J. Morph. 155, 35-61.

Burke, R. E., 1978: Motor units: Their physiological properties and neural connections. Amer. Zool., 18 (2), 121-134.

BurKe, R. E., and V. R. Edgerton, 1975: Motor unit properties and selective involvement in movement. In Exercise and Sport Sciences Reviews, 3, 31-81. Acad. Press, New York.

Burke, R. E., P. Tsairis, D. N. Levine, F. E. Zajac III, and W. K. Engel, 1973: Direct correlation of physiological and histochemical characteristics in motor units of cat triceps 
surae muscle. In J. E. DESMEDT: New Developments in Electromyography and Clinical Neurophysiology. 1, 23-30, Karger, Basel.

BUtLER, P. M., 1972: Some functional aspects of molar evolution. Evolution, 26, 474-483.

CARLSÖÖ, S., 1952: Nervous coordination and mechanical function of the mandibular elevators: an electromyographic study of the activity and an anatomic analysis of the mechanics of the muscles. Acta Odont. scand., 10 (Suppl. 11), 1-132.

Chase, M. H., and D. J. McGinty, 1970: Modulation of spontaneous and reflex activity of the jaw musculature by orbital cortical stimulation in the freely-moving cat. Brain Research, 19,117-126.

Close, R. J., 1972: Dynamic properties of mammalian skeletal muscles. Physiol. Rev., 52, $129-197$.

CoDy, F. W., and A. TAYLOR, 1973: The behaviour of spindles in the jaw-closing muscles during eating and drinking in the cat. J. Physiol., London, 231, 49-50.

CODY, F. W., R. W. LEE, and A. TAYLOR, 1972: A functional analysis of the components of the mesencephalic nucleus of the fifth nerve in the cat. J. Physiol., London, 226, 249-261.

Сrompton, A. W., 1966: On the lower jaw of Diartbrognathus and the origin of the mammalian lower jaw. Proc. Zool. Soc. London, 140, 697-753.

Crompton, A. W., 1971: The origin of the tribosphenic molar. In D. M. Kermack and K. A. KeRMACK : Early mammals. 65-87. Academic Press, London.

Crompton, A. W., 1972: Postcanine occlusion in cynodonts and tritylodontids. Bull. Brit. Mus. nat. Hist. (Geol.), $21(2), 1-71$.

Crompton, A. W., and K. Hiremae, 1970: Molar occlusion and mandibular movements during occlusion in the American opossum, Didelphis marsupialis (L.). Zool. J. Linn. Soc., 49, 21-47.

Crompton, A. W., and F. A. Jenkins, 1973: Mammals from reptiles: A review of mammalian origins.

Crompton, A. W., P. Cook, K. Hilemae, and A. J. Thexton, 1975: Movement of the hyoid apparatus during chewing. Nature, 258, (5530), 69-70.

Crompton, A. W., A. J. Thexton, P. Parker, and K. Hiremae, 1977: The activity of the jaw and hyoid musculature in the Virginian opossum, Didelphis virginiana. In B. STONEhouse, and D. Gilmore: The Biology of Marsupials. 287-305. MacMillan Press Ltd., New York.

Cundall, D., and C. Gans, 1977: A preliminary electromyographic analysis of ingestion by Nerodia (Serpentes, Reptilia). Amer. Zool., 17, 871 (Abstract).

Daunton, N. G., 1977: Sensory components of bite-force response in the rat. J. Comp. Physiol. Psych., 91, 203-220.

Dellow, P. G., and J. P. LuND, 1971: Evidence for central timing of rhythmical mastication. J. Physiol., London, 215, 1-13.

Denavit-Saubié, M., and J. Corvisier, 1972: Cat trigeminal motor nucleus: rhythmic units firing in relation to opening movements of the mouth. Brain Research, 40, 500-503.

DE VREE, F., 1977: Mastication in guinea pigs, Cavia porcellus. Amer. Zool., 17, 886 (Abstract).

DE VREE, F., and C. GANs, 1973: Masticatory responses of pigmy goats (Capra bircus) to different foods. Amer. Zool., 13, 1342-1343. (Abstract).

DE VREE, F., and C. GANS, 1976: Mastication in pigmy goats, Capra bircus. Ann. Soc. roy, Zool. Belg., 105, 255-306.

Du Brul, E. L., and H. Sicher, 1954: The Adaptive Chin. Charles C. Thomas, Springfield.

Edgerton, V. R., 1978: Mammalian muscle fiber types and their adaptability. Amer. Zool., $18(2), 113-125$.

EKSTEDT, J., and E. STÅLERG, 1973: Single fibre electromyography for the study of microphysiology of the human muscle. In: J. E. Desmedr: New Developments in Electromyography and Clinical Neurophysiology. 1,89-112. Karger, Basel.

ENDO, B., 1966: A biomechanical study of the human facial skeleton by means of strain-sensitive lacquer. Okajimas Fol. Anat. Jap., 42, 205-217.

Endo, B., 1970: Analysis of stresses around the orbit due to masseter and temporalis muscles, respectively. J. Anthrop. Soc. Nipon, 78, 251-266.

EnIEF, J., 1966: Materialverteilung und Beanspruchungsverteilung im coxalen Femurende. Inaug. Diss., Univ. Köln.

Evans, F. G., 1953: Methods of studying the biomechanical sequence of bone form. Amer. J. Phys. Anthrop., 11, 413-436.

Fisher, J. L., K. Godfrey, and R. I. Stephens, 1976: Experimental analysis of infant, adolescent and adult miniature swine skulls subjected to simulated mastication forces. J. Biomechanics, 9, 333-338.

GaNs, C., 1969: Comments on inertial feeding. Copeia, 1969 (4), 855-857.

GANs, C., and W. J. Bock, 1965: The functional significance of muscle architecture - a theoretical analysis. Ergebn. Anat. Entw. Gesch., 38, 115-142. 
Gans, C. and F. C. KalleN, 1972: Concepts in the analysis of the maxillomandibular apparatus. In G. H. Schmacher: Morphology of the Maxillo-Mandibular Apparatus. 154-159. G. Thieme Verlag, Leipzig.

GANS, C., and F. DE VREE, 1974: Correlation of accelerometers with electromyography in the mastication of pygmy goats (Capra bircus). Anat. Rec., 306 (Abstract).

Gaspard, M., 1971: Anatomie comparative et fonctionelle de la musculature masticatrice chez les carnivores. Mém. Mus. nat. Hist. Nat., N. S., (A) Zoologie, 63, 1-207.

Gaunt, A. S., and C. GaNs, 1969: Mechanics of respiration in the snapping turtle, Chelydra serpentina (Linné). J. Morph., 128, 195-228.

Gingerich, P. D., 1972: Molar occlusion and jaw mechanics of the Eocene primate Adapis. Amer. J. Phys. Anthrop., 36, 359-368.

Gingerich, P. D., 1973: Molar occlusion and function in the Jurassic mammal Docodon. J. Mamm., 54, 1008-1013.

Gingerich, P. D., 1974: Dental function in the Palaeocene primate Plesiadapis. In R. D. Martin, G. A. Doyle and A. C. Walker: Prosimian Biology II (B). 531-541. Dudkworth, London.

GiNGERICH, P. D., 1976: Molar occlusion and the mechanics of mastication in primates. Amer. J. Phys. Anthrop., 44, 180.

Goodwin, G. M., and E. S. Luschei, 1974: Effects of destroying spindle afferents from jaw muscles on mastication in monkeys. J. Neurophysiol., 37, 967-981.

Gorniak, G. C., 1977 a: Mastication in the domestic cat, Felis domestica. Anat. Rec., 187, 591 (Abstract).

Gorniak, G. C., 1977 b: Feeding in golden hamsters, Mesocricetus auratus. J. Morph., 154, $427-458$.

Gorniak, G. C., and C. Gans, 1977: Mastication of varying food types in cats. Felis domestica. Amer. Zool., 17, 886 (Abstract).

Gossow, G. E., ed. 1978: Skeletal muscle tissue: Form and function. Amer. Zool., 18 (2), 91-166.

GreENFIELD, B. E., and B. D. WYKE, 1956: Electromyographic studies of some of the muscles of mastication. Brit. Dent. J., 100, 129-143.

GrimbY, L., and J. HANNERz, 1968 : Recruitment order of motor units on voluntary contraction: changes induced by proprioceptive afferent activity. J. Neurol. Neurosurg. Psychiat., $31,565-573$.

Gydixov, A. A., and D. S. Kosarov, 1973: Physiological characteristics of the tonic and phasic motor units in human muscles. In A. A. Grdikov, N. T. TANkov and D. S. Kosarov: Motor control. 75-94. Plenum, New York.

Hannam, A. G., and B. Matthews, 1969: Reflex jaw opening in response to stimulation of periodontal mechanoreceptors in the cat. Archs. Oral Biol., 14, 415-419.

Hannam, A. G., B. Matthews, and R. Yemm, 1970: Receptors involved in the response of the masseter muscle to tooth contact in man. Archs. Oral Biol., 15, 17-24.

Hatze, H., and J. D. BuYs, 1977: Energy-optimal controls in the mammalian neuromuscular system. Biol. Cybernetics, 27, 9-20.

HendRichs, H., 1965: Vergleichende Untersuchungen des Wiederkauverhaltens. Biol. Zbl. 84, $651-751$.

Herring, S. W., 1976: The dynamics of mastication in pigs. Archs. Oral Biol., 21, 473-480.

Herring, S. W., 1977: Differential activity in complex muscles. Amer. Zool., 17, 954 (Abstract).

Herring, S. W., and R. P. Scapino, 1973: Physiology of feeding in miniature pigs. J. Morph., $141,427-460$.

Hess, A., 1970: Vertebrate slow muscle fibers. Phys. Revs., 50 (1), 40-62.

Hifemae, K. M., 1976: Masticatory movements in primitive mammals. In D. J. Anderson and B. MatThews: Mastication. 105-117. John Wright, B ristol.

Hingmae, K. M., and G. M. ARdRAN, 1968: A cinefluorographic study of mandibular movement during feeding in the rat (Rattus norvegicus). J. Zool., 154, 139-154.

Hiemae, K. M., and A. W. Crompton, 1971: A cinefluorographic study of feeding in the American opossum, Didelphis marsupialis. In A. A. DAHLberg: Dental Morphology and Evolution. 299-334. University of Chicago Press.

HiremAE, K. M., and R. F. KAY, 1973: Evolutionary trends in the dynamics of primate mastication. In M. R. ZingesER: Craniofacial Biology of Primates. Karger, Basel. Symp. 4th Int. Cong. Primat., 3, 28-64.

Hitemae, K. M., and A. J. Thexton, 1975: Consistency and bite size as regulators of mastication in cats. IADR Abstracts, 54, L94.

Hildebrand, G. Y., 1937: A further contribution of mandibular kinetics. J. Dent. Res., 16, $551-559$.

HYLANDER, W. L., 1977: In vivo bone strain in the mandible of Galago crassicaudatus. Amer. J. Phys. Anthrop., 46, 309-326. 
JARABAK, J. R., 1957: An electromyographic analysis of muscular behavior in mandibular movements from rest position. J. Prosth. Dent., 7, 682-710.

Jerge, C., 1964: The neurologic mechanism underlying cyclic jaw movements. J. Prosth. Den., $14,667-681$.

KaKUdO, Y., and N. Amano, 1970: Strain gauges used in studying strain on the human and animal jaw bones during occlusion, mastication and swallowing. J. Osaka Dent. Univ., $4,1-13$.

Kallen, F. C., and C. Gans, 1972: Mastication in the little brown bat, Myotis lucifugus. J. Morph., 136, 385-420.

Kavamura, Y., 1967: Neurophysiologic badkground of occlusion. Periodontics, 5, 175-183.

KaWAMURA, Y., M. Funakoshi, and M. TAKata, 1960: Reciprocal relationships in the brainstem among afferent impulses from each jaw muscle on the cat. Jap. J. Physiol., 10, $585-593$.

Kawamura, Y., T. Majima, and I. Kato, 1967: Physiologic role of deep mechanoreceptor in temporomandibular joint capsule. J. Osaka Univ. Dental School, 7, 63-76.

KAY, R., 1975: The functional adaptions of primate molar teeth. Amer. J. Phys. Anthrop., $43,195-216$.

Kay, R. F., and K. M. Hiremae, 1974 a: Jaw movement and tooth use in recent and fossil primates. Amer. J. Phys. Anthrop., 40, 227-256.

KAY, R. F., and K. M. HiIEMAE, 1974 b: Mastication in Galago crassicaudatus, a cinefluorographic and occlusal study. In R. D. Martin, G. A. Doyle and A. C. Walker: Prosimian Biology, 501-530. Duckworth, London.

Kidokoro, Y., K. Kubota, S. Shuto, and R. Sumino, 1968: Reflex organization of cat masticatory muscles. J. Neurophysiol., 31, 695-708.

KLinEBERG, I., 1971: Structure and function of the temporomandibular joint innervation. Ann. Roy. Coll. Surg. Engl., 49, 268-288.

KlineberG, I., B. E. GReenfield, and B. D. WYKe, 1970: Contributions to the reflex control of mastication from mechanoreceptors in the temporomandibular joint capsule. Dent. Pract., 21, 73-83.

Kummer, B., 1966: Photoelastic studies on the functional structure of bone. Folia biotheor., $6,31-40$.

Lund, J. P., and B. J. SEssle, 1974: Oral-facial and jaw muscle afferent projections to neurons in cat frontal cortex. Exptl. Neurol., 45, 314-331.

LusCHEI, E. S., and G. M. GoodwiN, 1974: Patterns of mandibular movement and jaw muscle activity during mastication in the monkey. J. Neurophysiol., 37, 954-966.

Magoun, H. W., S. W. RANSON, and C. Fisher, 1933: Corticifugal pathways for mastication, lapping and other motor functions in the cat. Arch. Neurol. Psych., 30, 292-308.

McNamara, J. A., Jr., 1972: Neuromuscular and skeletal adaptations to altered orofacial function. Center for Human Growth and Development, Univ. Mid., Ann Arbor, Mongr. (1), Craniofacial Growth Series, 1-150.

McNamara, J. A., Jr., 1974: An electromyographic study of mastication in the rhesus monkey (Macaca mulatta). Archs. Oral Biol., 19, 821-823.

Mills, J. R. E., 1967: A comparison of lateral jaw movements in some mammals from wear facets on the teeth. Arch. Oral Biol. 12, 645-661.

Møller, E., 1966: The chewing apparatus. An electromyographic study of the action of the muscles of mastication and its correlation to facial morphology. Acta Physiol scand., 69 (Suppl. 280), 1-229.

MOYERS, R. E., 1950: An electromyographic analysis of ccrtain muscles involved in temporomandibular movement. Amer. J. Orthodont., 36, 481-516.

Noyes, D. H., and C. W. SALT, 1977: Elastic response of the temporomandibular joint to very small forces. J. Periodont., $48,98-100$.

Olson, E. C., 1971: Vertebrate Paleozoology. Wiley Interscience, New York.

Olson, C. B., D. O. Carpenter, and E. Henneman, 1968: Orderly recruitment of muscle action potentials. Motor unit threshold and EMG amplitude. Arch. Neurol., 19. $591-597$.

OSBORN, J. W., and A. W. CROMPTON, 1973: The evolution of mammalian from reptilian dentitions. Breviora, Mus. Comp. Zool., 399, 1-18.

Pond, C. M., 1977: The significance of lactation in the evolution of mamnals. Evolution, 31, $177-199$.

Rensberger, J. M., 1973: An occlusion model for mastication and dental wear in herbivorous mammals. J. Paleont., 47, 515-528.

Rioch, J. McK., 1934; The neural mechanism of mastication. Amer. J. Physiol., 108, 168-176.

Romer, A. S., 1966: Vertebrate Paleontology. University of Chicago Press, 3rd ed.

Kosenberg, H., and C. Gans, 1977: Preliminary analysis of mastication in Sphenodon punc* tatus. Amer. Zool., 17, 871 (Abstract).

Seipel, C. M., 1948: Trajectories of the jaws. Acta Odont. scand., 8, 81-191. 
Scapino, R. P., 1965: The third joint of the canine jaw. J. Morph., 116, 23-50.

Schumacher, G. H., 1961: Funktionelle Morphologie der Kaumuskulatur. Gustav Fischer, Jena.

Sherrington, C. S., 1917: Reflexes elicitable in the cat from pinna, vibrissae and jaws. J. Physiol., London, 51, 404-431.

Simpson, G. G., 1945: The principles of classification and a classification of mammals. Bull. Amer. Mus. nat. Hist., 85 , i-xvi $+1-350$.

Smith, J. M., and R. SAvage, 1959: The mechanics of mammalian jaws. School Sci. Rev., 40, 289-301.

STÅlbERG, E., and J. EKsTEDT, 1973: Single fibre EMG and microphysiology of the motor unit in normal and diseased human muscle. In J. E. DesmedT: New Developments in Electromyography and Clinical Neurophysiology, 1, 113-129. Karger, Basel.

Stöcker, L., 1957: Trigeminusmuskulatur und Kiefergelenk von Elephas maximus. L. Morph. Jb., 98 (1), 35-76.

StorCH, G., 1968: Funktionsmorphologische Untersuchungen an der Kaumuskulatur und an korrelierten Schädelstrukturen der Chiropteren. Abh. senckenb. naturf. Ges., 517, 1-92.

Sumi, T., 1977: Modification of cortically evoked rythmic jaw movements by reflex deglulution in rabbits. Jap. J. Physiol., 27, 391-398.

Suzukr, A., 1977: A comparative histochemical study of the masseter muscle of cattle, sheep, swine, dog, guinea pig, and rat. Histochemistry, 51,121-131.

TAPPEN, N. C., 1953: A functional analysis of the facial skeleton with split-line technique. Amer. J. Phys. Anthrop., 11, 503-532.

TAPPEN, N. C., 1964: An examination of alternative explanations of split-line orientation in compact bone. Amer. J. Phys. Anthrop., 22, 423-442.

TAYLOR, A., and M. R. DAVEY, 1968: Behaviour of jaw muscle stretch receptors during active and passive movements in the cat. Nature, 220,301-302.

TAYLOR, A., F. W. CODY, and M. A. BosLEY, 1973: Histochemical and mechanical properties of the jaw muscles of the cat. Exptl. Neurol., 38, 99-109.

Thexton, A. J., 1976: To what extent is mastication programmed and independent of peripheral feed-badk? In D. J. Anderson and B. MatrHews: Mastication. 213-220. John Wright, Bristol.

Thexton, A. J., and K. M. Hinemae, 1975: Masticatory electromyographic activity as a function of food consistency. IADR Abstracts, 54, L 95.

Thexton, A. J., and K. M. Hilemae, 1977: A radiographic and electromyographic study of snapping and biting in the opossum. Ardis. oral. Biol., 22, 303-308.

THRockMorToN, G. S., 1976: Oral food processing in two herbivorous lizards. Iguana iguana (Iguanidac) and Uromastix aegyptius (Agamidae). J. Morph., 148, 363-390.

Turnbul, W. D., 1970: Mammalian masticatory apparatus. Fieldiana: Geology, 18, $149-356$.

VITTI, M., and J. V. BASMAJIAN, 1977: Integrated actions of masticatory muscles: simultaneous EMG from eight intramuscular electrodes. Anat. Rec., 187, 173-190.

WEIJS, W. A., 1975: Mandibular movements of the albino rat during feeding. J. Morph., 145, $107-124$.

WEIJS, W. A., and R. DANTUMA, 1975: Electromyography and mechanics of mastication in albino rat. J. Morph., 146, 1-34.

WEIJS, W. A., and H. J. DEJONGH, 1977: Strain in mandibular alveolar bone during mastication in rabbits. Arch. Oral Biol., 22, 667-675.

Wetzel, M. C., and D. G. StuART, 1976: Ensemble characteristics of cat locomotion and its neural control. Prog. Neurobiol., 71, 1-98.

Woods, C. A., 1976: How hystricognath rodents chew. Amer. Zool., 16, 215 (Abstract).

WRIGHT, T. M., and W. C. HAYES, 1976: Tensile testing of bone over a wide range of strain rates: cffects of strain rate, microstructure and density. Med. Biol. Eng., 14, 671-679.

Authors address: See title page. 